\title{
AN EXPERIMENTAL STUDY ON FRICTION DRILLING OF ST12 STEEL
}

\author{
Mehmet Tuncay Kaya ${ }^{1}$, Alaattin Aktas ${ }^{2}$, Bertan Beylergil ${ }^{3}$ and Hamza K. Akyildiz ${ }^{1}$ \\ ${ }^{1}$ Department of Mechanical Engineering, Faculty of Engineering and Architecture, \\ Bozok University, 66000 Yozgat, Turkey \\ ${ }^{2}$ Department of Mechanical Engineering, Faculty of Engineering, Istanbul University, \\ 34320 Avcilar, Istanbul, Turkey \\ ${ }^{3}$ Department of Mechanical Engineering, Faculty of Engineering, Izmir Institute of Technology, \\ 35347 Urla, Izmir, Turkey \\ E-mail: bertanbeylergil@iyte.edu.tr; aktasa@istanbul.edu.tr
}

Received May 2013, Accepted May 2014

No. 13-CSME-134, E.I.C. Accession 3592

\begin{abstract}
The aim of this study is to investigate the effects of drilling parameters such as friction angle, friction contact area ratio (FCAR), feed rate and spindle speed on workpiece surface temperature, thrust force and torque in friction drilling of ST12 material. The tool material is tungsten carbide coated with TiN treatment. Experimental results reveal that the thrust force and torque increases gradually with increasing friction angle, feed rate and FCAR. On the other hand, the thrust force and torque decreases with increasing drilling speed. It is found that drilling speed has an important effect on the workpiece surface temperature. As the drilling speed increases, the workpiece surface temperature increases. Increasing or decreasing the friction angle and FCAR has no significant effect on the workpiece surface temperature.
\end{abstract}

Keywords: chipless hole making; ST12; friction angle; FCAR; feed rate; spindle speed.

\section{UNE ÉTUDE EXPÉRIMENTALE SUR LE PERÇAGE PAR FRICTION D’UN ACIER ST12}

\section{RÉSUMÉ}

Le but de l'étude est d'investiguer les effets des paramètres de friction, tels que l'angle de friction, le rapport de l'aire de contact de la friction (friction contact area ratio (FCAR); la vitesse d'avancement et la vitesse de la broche sur la température de la surface de la pièce, et la poussée force et torsion dans le perçage par friction d'un acier ST12. La composition de l'outil est faite de carbure et de tungstène recouvert d'étain. Les résultats des expériences révèlent que la poussée force et torsion augmente graduellement avec l'accroissement de l'angle de friction, la vitesse d'avancement et le FCAR. D'autre part, la poussée force et torsion diminue avec l'accroissement de la vitesse du perçage. On constate que la vitesse du perçage a un effet important sur la température de la surface de la pièce. Au fur et à mesure que la vitesse de perçage augmente, la température de la surface de la pièce s'accroît. L'augmentation ou la diminution de l'angle de friction et le FCAR n'a aucun effet significatif sur la température de la surface de la pièce.

Mots-clés : perçage sans copeaux; ST12; angle de friction; FCAR; vitesse d'avancement; vitesse de la broche. 


\section{INTRODUCTION}

Drilling plays a very important role in machining since more than $40 \%$ of material removal processes are associated with this type of operation. Traditionally, a drilling tool is generally made of high speed steel (HSS). It generates high temperature during drilling process. Therefore, the drilling tool becomes dull and leads to a shortened service life. Moreover, the workpiece materials have been hardened during drilling process which makes the post-process troublesome. Also, the chips adhered to the exit of a drilled hole damages the surface quality and deteriorates the machining precision. Friction drilling, also known as "thermal drilling", "flow drilling", "form drilling", or "friction stir drilling", is the best solution to the aforementioned problems [1-3].

Friction drilling utilizes the heat generated from the friction between a rotating conical tool and the workpiece. The tool is often made of tungsten carbide and rotates at high speed, which produces friction heat. The process forms a bushing in situ and is clean and chipless. This chipless machining process has the advantage of reducing the time required for drilling and incurring less tool wear, thus lengthening the service life of the drill. Also, unlike traditional drilling that uses cutting fluid to reduce the friction and heat generation, friction drilling is a dry process $[4,5]$.

Research on the subject of friction drilling is rare and the following review summarizes some of these studies; Ku et al. [5] developed a new type of thermal friction drill made of sintered carbide and they investigated the effects of friction angle, friction contact area ratio, feed rate, and spindle speed on the two quality characteristics, surface roughness and bushing length. They reported the optimal machining parameters for surface roughness and bushing length. Lee et al. [6] applied friction drilling method to IN- 713LC cast and examined different quality characteristics such as hole roundness, surface roughness and hardness of hole wall. France [7-9] studied the strength characteristics of friction drilled holes in metal tubes. Chow et al. [10] carried out experiments using AISI304 stainless steel as a workpiece material and showed that the drilled surroundings area obtained fine grain size and compact structure with a higher micro hardness than that of the area away from the drilled area. Miller et al. [11] applied friction drilling to machine different materials viz. low-carbon steel, aluminum and magnesium alloys and investigated the relationship between axial thrust force and torque under different spindle speeds and feed rates experimentally. Lee et al. [12] utilized friction drilling to make holes using tungsten carbide drills with and without coating in AISI 304 stainless steel. The authors showed that coated drills suffered less tool wear than uncoated drills at the same spindle speed and for the same number of holes drilled. Folea et al. [13] studied friction drilling of two types of maraging steel workpieces (flat and cylindrical). The authors showed that temperature was the most significant factor in friction drilling process. They also reported that superior quality of the drilled holes could be obtained with higher speeds both on flat and cylindrical workpieces.

However, there is no research related specifically to ST12 steel as a workpiece material for friction drilling process. ST12 steel is being widely used such as automobile manufacturing, electrical products, rolling stock, aerospace, precision instruments and is a good candidate for friction drilling. Therefore, the novel process of the thermal friction drilling needs a further and comprehensive study to understand the effects of drilling parameters on ST12 steel. The main purpose of this paper is to investigate the effects of some machining parameters of the thermal friction drilling process on ST12 steel. The machining parameters are considered as follows: friction angle (300, 450 and 600), friction contact area ratio (FCAR, 50 and 100\%), feed rate (from 100 to $500 \mathrm{~mm} / \mathrm{min}$ with an increment of $50 \mathrm{~mm} / \mathrm{min}$ ) and spindle speed (3000, 4500 and $6000 \mathrm{rpm})$. The effects of these parameters on workpiece surface temperature, thrust force and torque are examined. Experimental results show that the thrust force and torque increases gradually as friction angle, feed rate and FCAR increase. On the other hand, the thrust force and torque decreases as spindle speed increases. The results reveal that spindle speed has an important effect on the workpiece surface 


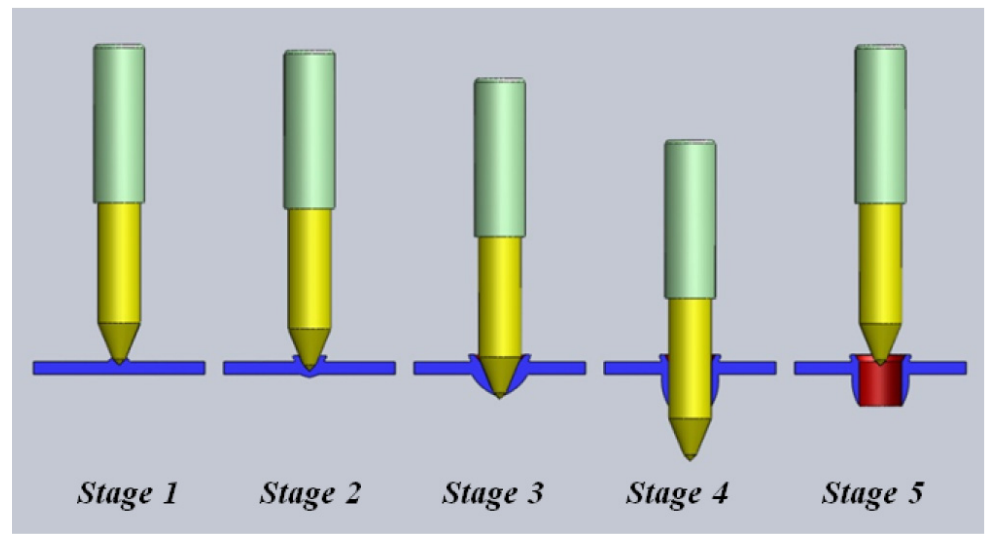

Fig. 1. Stages of friction drilling.
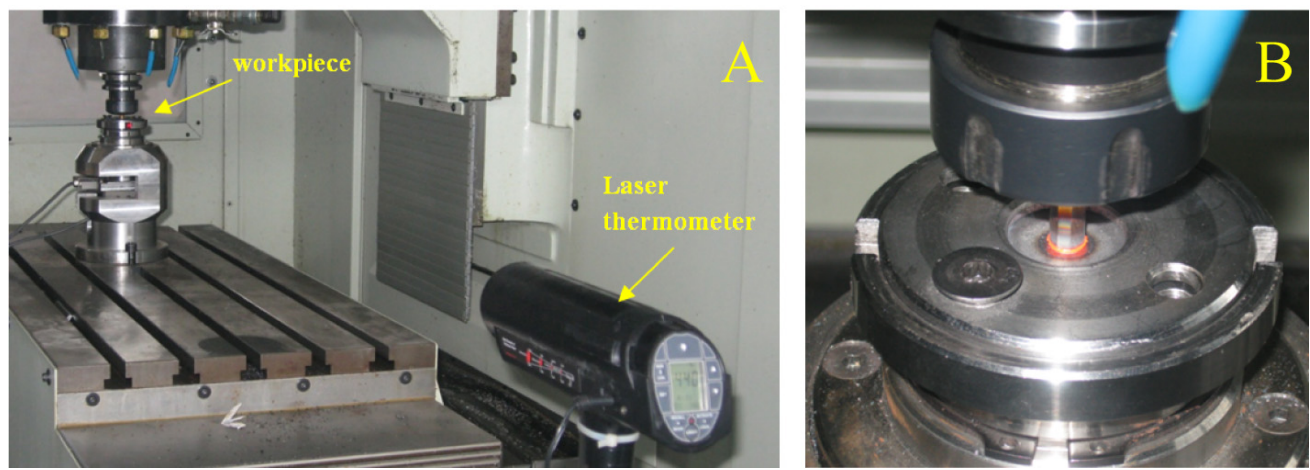

Fig. 2. Experimental test-setup (a) overview and (b) close-up view.

temperature. As the spindle speed increases, the workpiece surface temperature increases. Increasing or decreasing the friction angle and FCAR has no significant effect on surface temperature.

\section{EXPERIMENTAL}

Figure 1 shows the five stages during friction drilling. The tip of the conical tool approaches and contacts the workpiece in stage 1 . In stage 2, the friction drill has nearly penetrated the specimen due to the continuation of the drilling process. The thrust force is typically at its maximum, and the back extrusion of specimen can be observed at this stage. Then, the friction drill penetrates the specimen in stage 3 . This is the friction drill location where the maximum torque is observed. In stage 4, the tool moves further forward to push aside more work-material and form the bushing using the cylindrical part of the tool. Then, in stage 5, the friction drill is quickly withdrawn from the hole [14].

\subsection{Machine and Workpiece}

A three-axis computer numerical controlled vertical machining center, CNC Machining Center MCV 300 First, with a maximum spindle speed of $8000 \mathrm{rpm}$ and spindle motor of $11 \mathrm{~kW}$, is used for the friction drilling experiment. The overview of the friction drill test setup is shown in Fig. 2.

The work piece is disc-shaped ST12 steel with $36 \mathrm{~mm}$ diameter and $2 \mathrm{~mm}$ thickness. The chemical composition of ST12 material is shown in Table 1. 
Table 1. Chemical composition of ST12 steel.

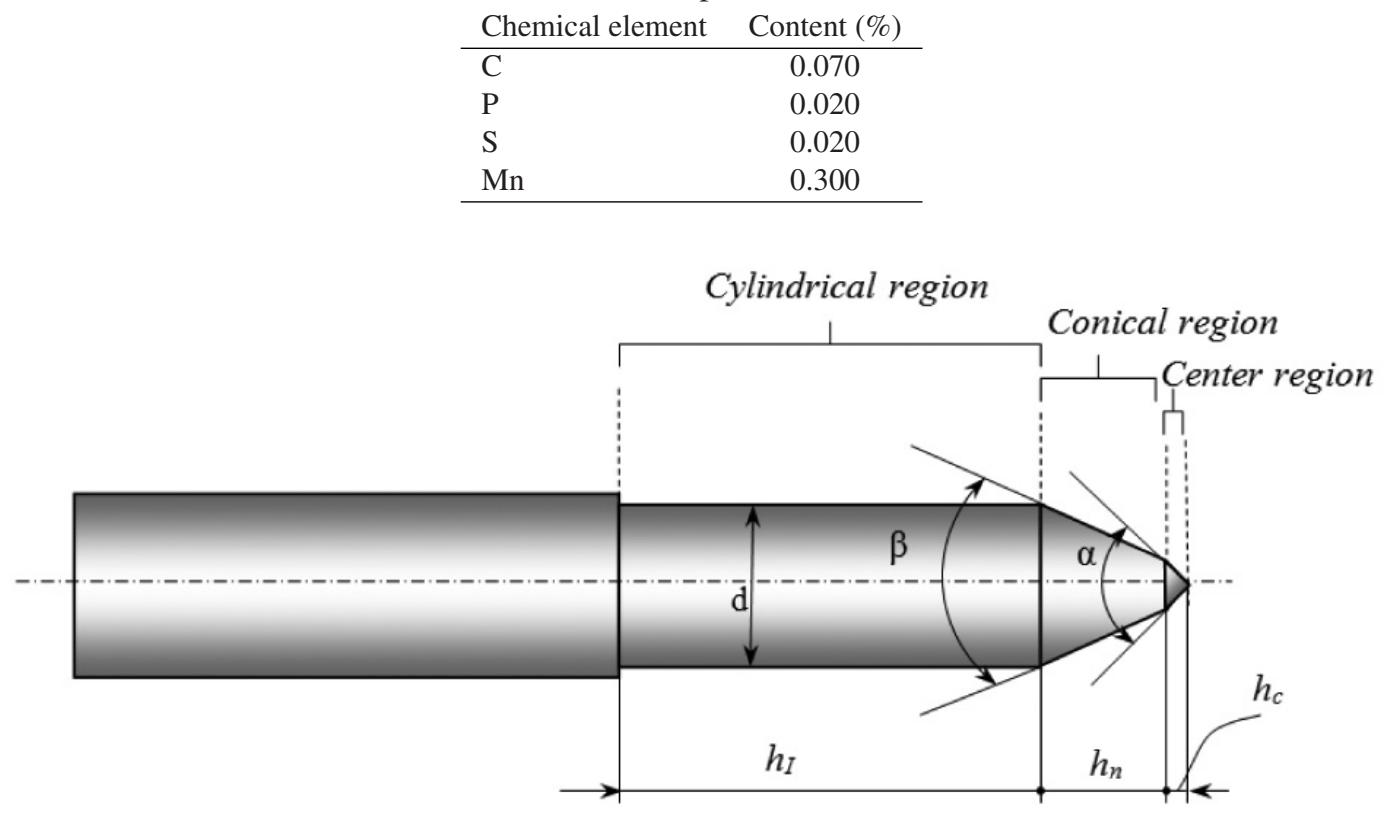

Fig. 3. Shape of a typical friction drilling tool.

Table 2. Dimensions of the friction drilling tools used in this study.

\begin{tabular}{lccccc}
\hline$B\left({ }^{\circ}\right)$ & $d(\mathrm{~mm})$ & $h_{l}(\mathrm{~mm})$ & $h_{n}(\mathrm{~mm})$ & $h_{c}(\mathrm{~mm})$ & $\alpha\left(^{\circ}\right)$ \\
\hline 30 & 6.7 & 19 & 8.77 & 1 & 90 \\
45 & 6.7 & 19 & 5.67 & 1 & 90 \\
60 & 6.7 & 19 & 4.07 & 1 & 90 \\
\hline
\end{tabular}

\subsection{Tools}

Figure 3 shows a typical friction drilling tool. As visualized, the tool consists of three regions [15]. The first one is the center region. It has an angle $\alpha$ and height $h_{c}$. This region provides the support in the radial direction for the friction drilling process and keeps the drill from walking at the start of the drilling process. The tools used in this study has $\alpha=900$ and $h_{c}=1 \mathrm{~mm}$. The second one is the conical region. It has a sharper angle than the center region.

The tool in this region rubs against the workpiece to generate the friction force and heat, and pushes the work-material sideward to shape the bushing. The friction angle and length of the cone-shape conical region are marked as $\beta$ and $h_{n}$, respectively. Three different friction angles $30^{\circ}, 45^{\circ}$ and $60^{\circ}$ are considered. Lastly, the cylindrical region is the third region. It helps to form the hole and shape of the bushing. The length and diameter of this region are designated as $h_{l}$ and $d$, respectively. The tools are $d=6.7 \mathrm{~mm}$ and $h_{l}=19 \mathrm{~mm}$.

Table 2 shows the keys dimensions of the tools. The tools are made by tungsten carbide of cylindrical bars with super fine grain size.

As recommended by Adachi et al. [16], the tool material is coated with TiN treatment in order to prolong tool life and reach higher drilling speeds. The tools are ground into conical shape using a diamond grinder shown in Fig. 4a. It shows that the friction contact area ratio (FCAR) is $100 \%$. In order to compare their performance, the tools are ground into a four-leaf: four friction contact areas. In this case, the FCAR is 50\% and is shown in Fig. 4b. 

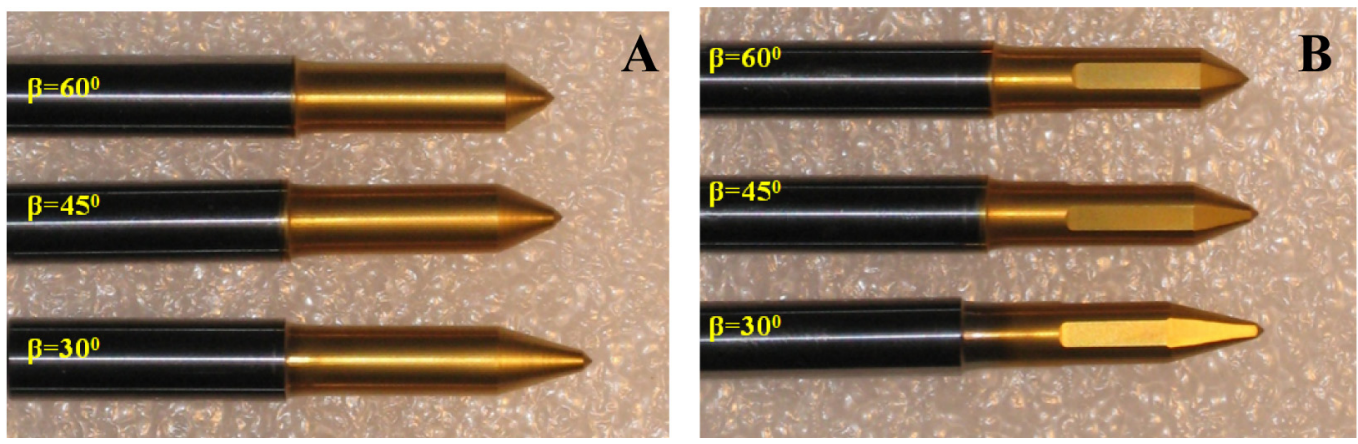

Fig. 4. Front and side views of the tools with different FCARs (a) $100 \%$ and (b) $50 \%$.

Table 3. Machining conditions of thermal friction drilling.

\begin{tabular}{ll}
\hline Factors & Parameters \\
\hline FCAR $(\%)$ & 50,100 \\
Friction angle, FA $\left(^{\circ}\right)$ & $30,45,60$ \\
Feed rate (mm/min) & from 100 to 500 (with an increment of 50) \\
Drilling speed (rpm) & $3000,4500,6000$ \\
\hline
\end{tabular}

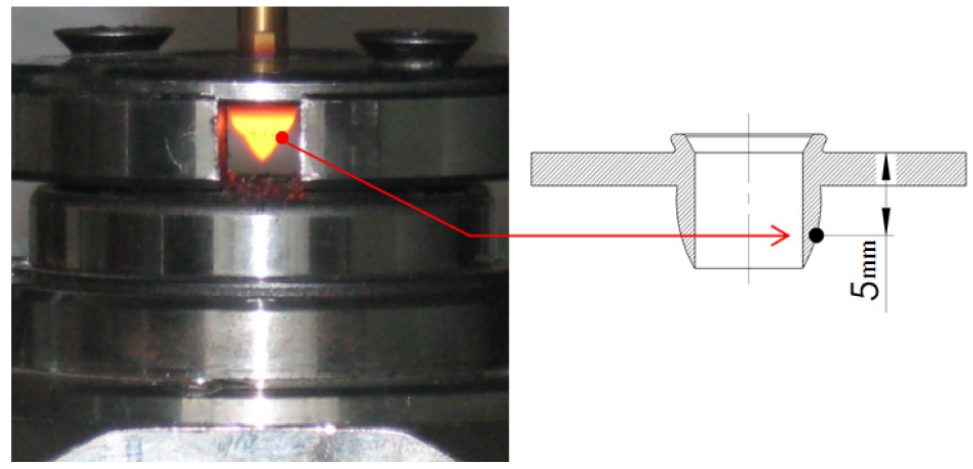

Fig. 5. Location of temperature measurement.

\subsection{Experimental Procedures}

Table 3 lists the machining condition of friction drilling used in this study. During the drilling process, specimens are fixed tightly on drilling dynamometer with a load cell sensor and set on the pallet of the vertical machining center. In order to ensure that the specimens remain undamaged during the drilling process, an appropriate space is machined on the dynamometer and the specimens are placed to this space by connecting lugs and bolts. The sampling rate of the data logger is $2000 \mathrm{~Hz}$. After the acquisition is complete, the data is transferred to a PC with a datalogger.

An infrared thermometer (Raytek $3 \mathrm{i}$ Series) is used to measure workpiece surface temperature. The range of the thermometer is 150 to $1800^{\circ} \mathrm{C}$ with a maximum error of $1.0^{\circ} \mathrm{C}$. In order to get an accurate temperature reading, a channel is machined in the head of dynamometer. The temperature is measured from the location where the bushing of the hole is formed (Fig. 5).

The mean surface roughness $\left(R_{a}\right)$ is measured with a MarSurf PS1 portable surface roughness tester instrument. The measurement needle has a diameter of $2 \mu \mathrm{m}$ and an average pressure force of $0.7 \mathrm{mN}$. The cutoff and sampling lengths for each measurement are taken as 0.8 and $5.6 \mathrm{~mm}$, respectively. A minimum of 10 measurements are taken. The highest and lowest values are discarded, and the average value is recorded. 
$3000 \mathrm{rpm} \% 100$ FCAR FRICTION DRILLING SURFACE TEMPERATURES

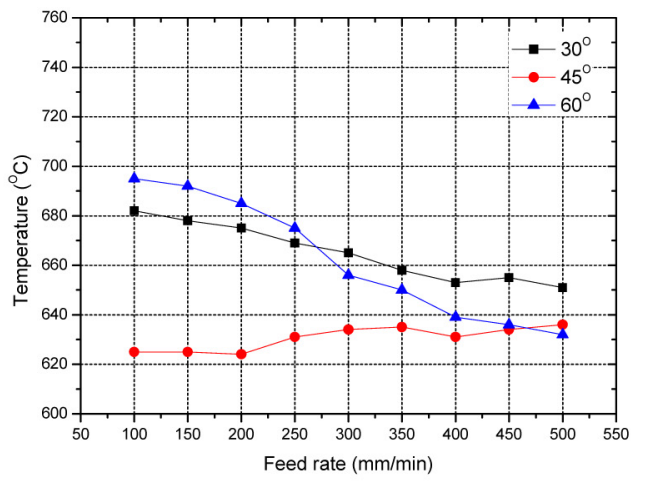

(a)

4500 rpm \%100 FCAR FRICTION DRILLING SURFACE TEMPERATURES

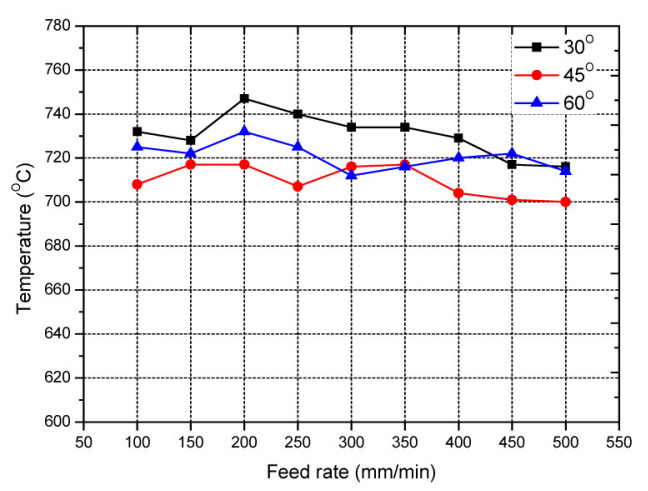

(c)

$6000 \mathrm{rpm} \% 100$ FCAR FRICTION DRILLING SURFACE TEMPERATURES

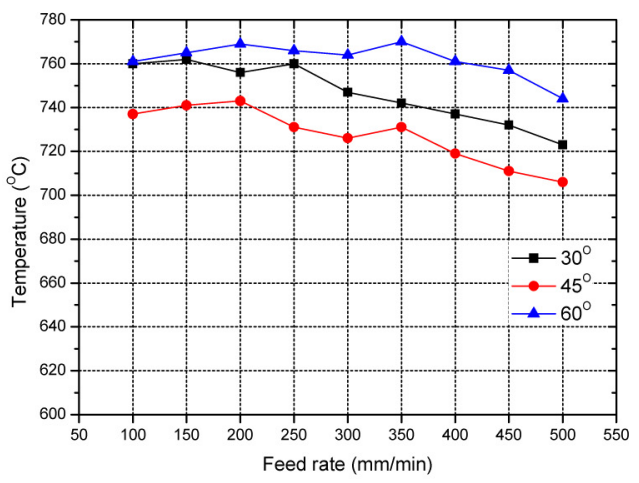

(e)
3000 rpm \%50 FCAR FRICTION DRILLING SURFACE TEMPERATURES

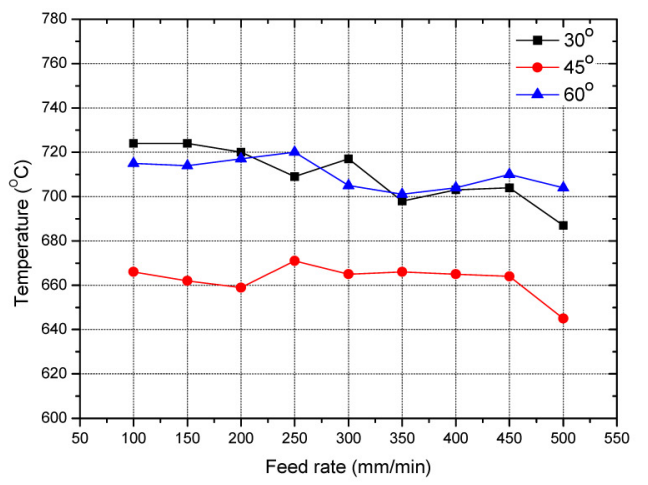

(b)

$4500 \mathrm{rpm} \% 50$ FCAR FRICTION DRILLING SURFACE TEMPERATURES

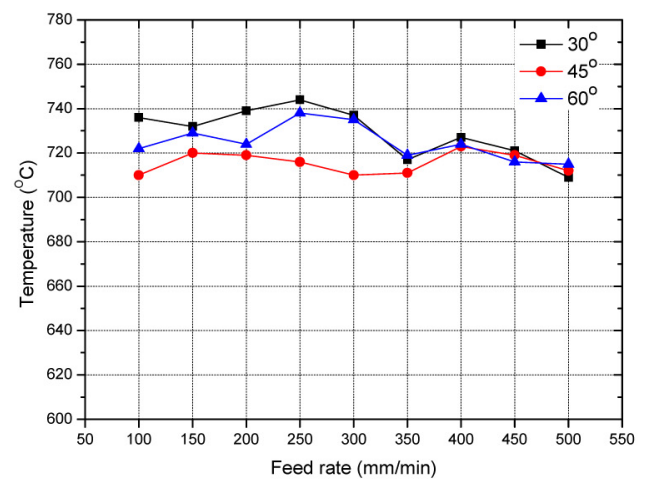

(d)

$6000 \mathrm{rpm} \% 50$ FCAR FRICTION DRILLING SURFACE TEMPERATURES

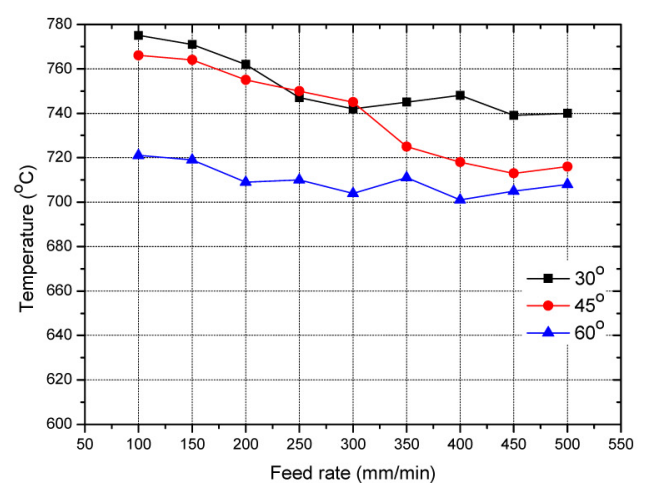

(f)

Fig. 6. Workpiece surface temperature variation with respect to different machining conditions. 


\section{RESULTS AND DISCUSSION}

\subsection{Workpiece Temperature}

Figure 6 shows the variation of workpiece surface temperature according to the examined parameters. As seen in Fig. 6(a), the minimum surface temperature of $6240 \mathrm{C}$ is obtained when the drilling is performed by a drilling tool with 450 friction angle and $100 \%$ FCAR under the operation condition of spindle speed of $3000 \mathrm{rpm}$, and feed rate of $100 \mathrm{~mm} / \mathrm{min}$. The results reveal that generally the temperature measured in drilling operations performed by a drilling tool with 450 friction angle is lower than drilling tools with angles of $30^{\circ}$ and $60^{\circ}$. As seen in Fig. 6(f), the maximum surface temperature of $775^{\circ} \mathrm{C}$ is obtained when drilling is performed by a drilling tool with $30^{\circ}$ friction angle and 50\% FCAR under the operating condition of spindle speed of $6000 \mathrm{rpm}$, and feed rate of $100 \mathrm{~mm} / \mathrm{min}$. The reason is that the hn length of the drilling tool is longer compared with hn length of drilling tolls with friction angles of 45 and $60^{\circ}$. The $h_{n}$ length being longer, causes the piece to be drilled quicker during the drilling operation and causes the pressure between drilling tool and workpiece to occur in a narrower area. It is observed that surface temperature increases with the increase of spindle speed and vice versa. The results are similar to those reported by Miller et al. [1].

It is also observed that the friction contact area ratio does not have a significant effect on surface temperature while spindle speed and feed rate are constant. For example, in Fig. 6(c), a surface temperature of $708^{\circ} \mathrm{C}$ is obtained when drilling is performed by a drilling tool with $45^{\circ}$ friction angle under the operating conditions of spindle speed of $4500 \mathrm{rpm}$, feed rate of $100 \mathrm{~mm} / \mathrm{min}$. It can be seen that the temperature is $710^{\circ} \mathrm{C}$ under the same conditions (Fig. 6d).

Figure 7 shows the photographs of the bushings under various friction angles. The measured surface roughness and bushing length values are also shown in the figure. The spindle speed is kept constant at $6000 \mathrm{rpm}$. The FCAR is $100 \%$. It can be seen in the figure that there is an increase in surface roughness as the feed rate increases. The rapid feed increase causes distorted grain boundary which decreases the surface roughness. The bushing length decreases as the feed rate increases.

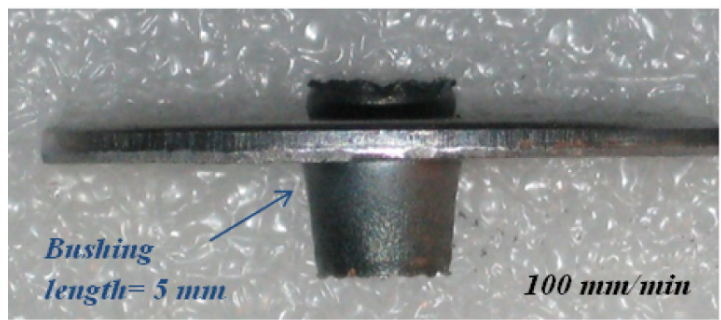

(a)

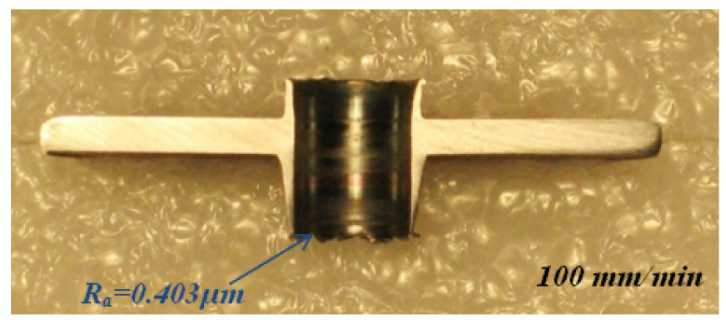

(b)
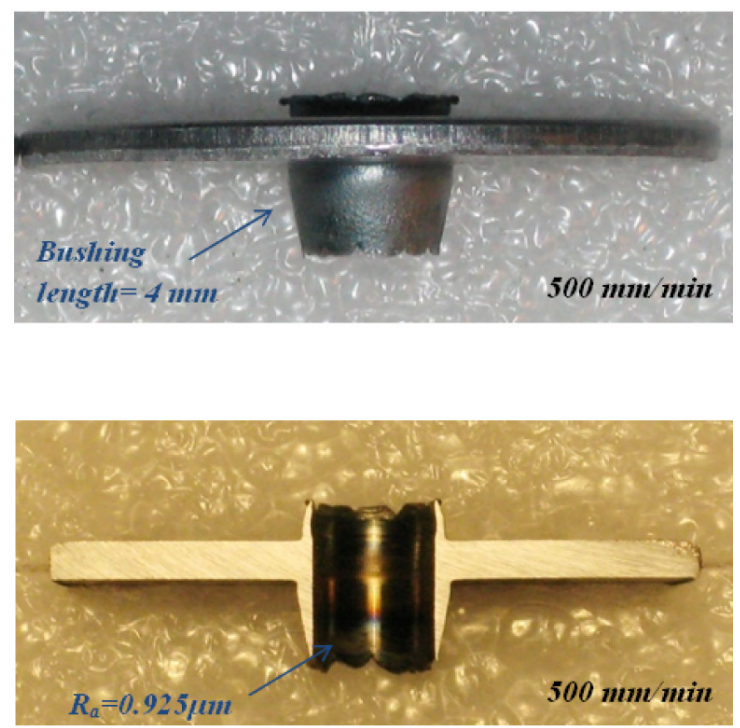

Fig. 7. Images of (a) overview and (b) cross-sections of friction-drilled holes obtained from various feed rates (under the condition of drilling speed $=6000 \mathrm{rpm}, \mathrm{FCAR}=100 \%$ and $\beta=30^{\circ}$ ). 


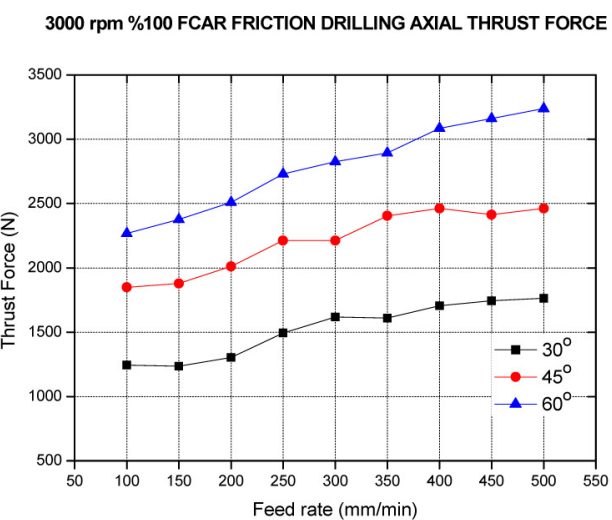

(a)

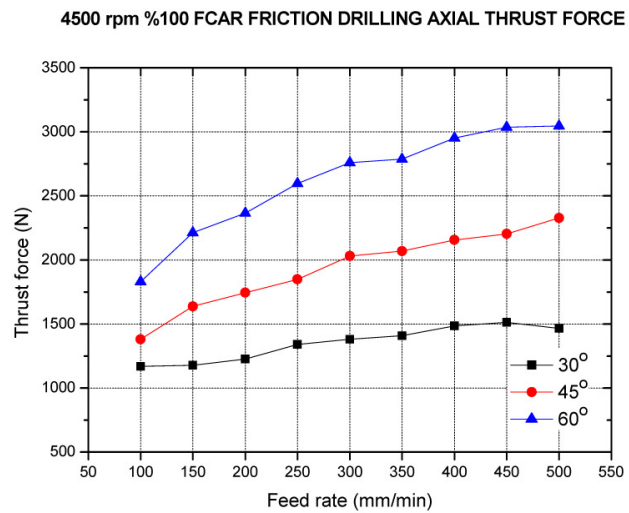

(c)

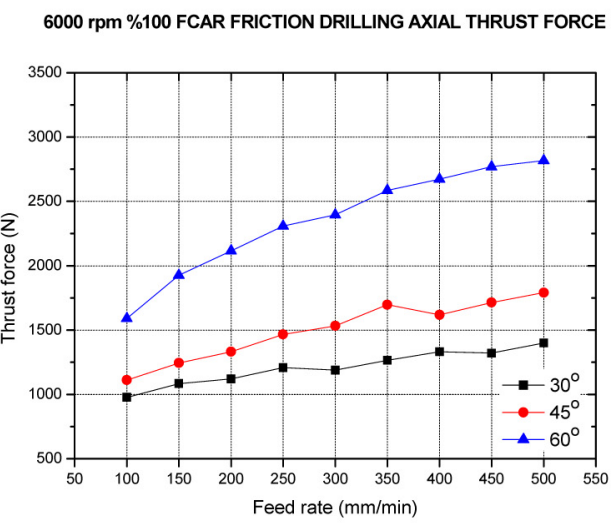

(e)

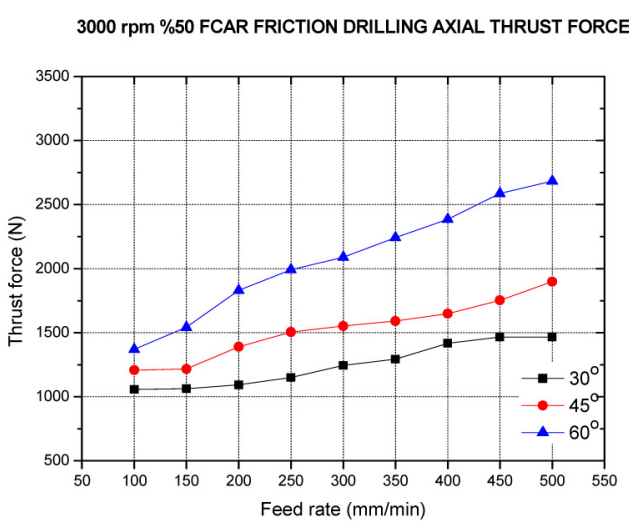

(b)

4500 rpm \%50 FCAR FRICTION DRILLING AXIAL THRUST FORCE

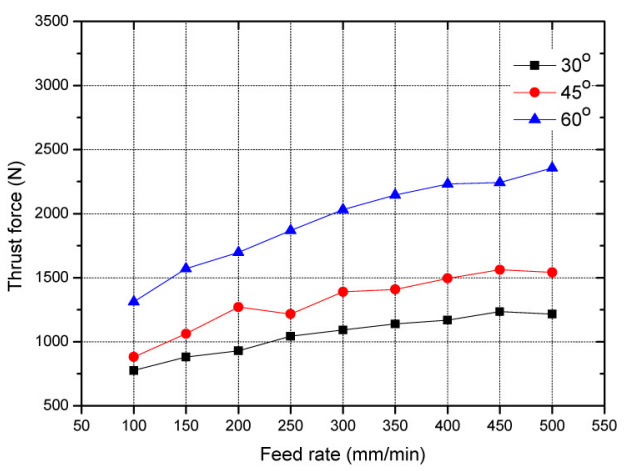

(d)

$6000 \mathrm{rpm} \% 50$ FCAR FRICTION DRILLING AXIAL THRUST FORCE

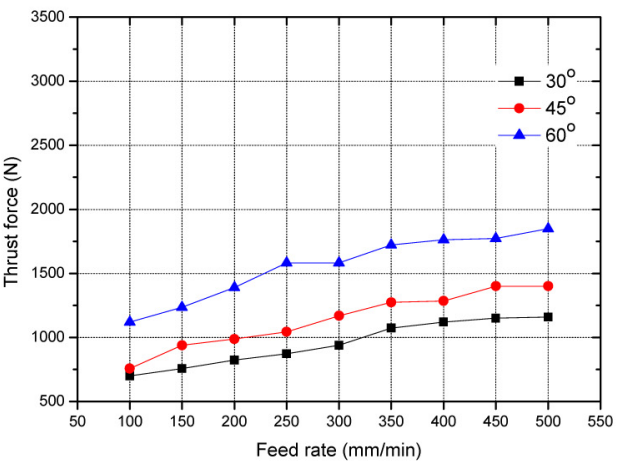

(f)

Fig. 8. Axial thrust force variation with respect to different machining condition. 


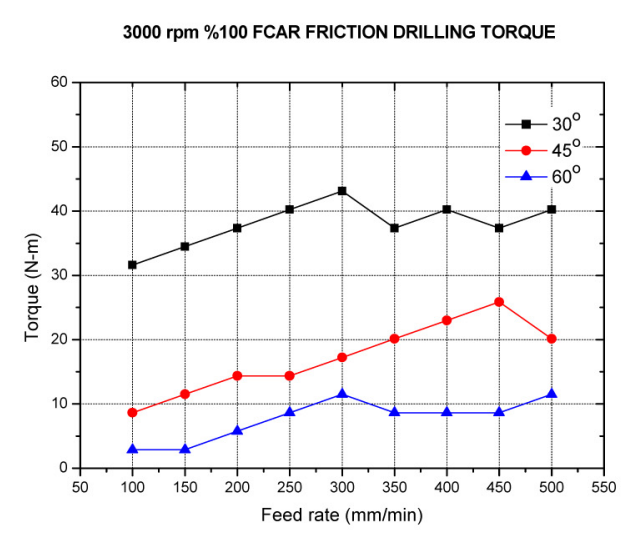

(a)

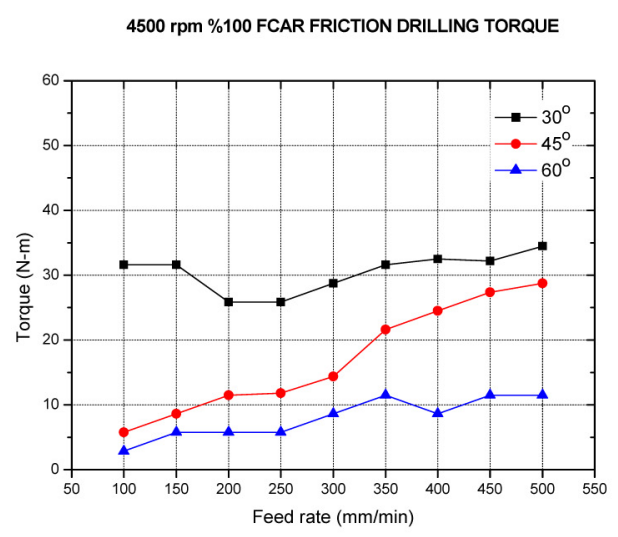

(c)

$6000 \mathrm{rpm} \% 100$ FCAR FRICTION DRILLING TORQUE

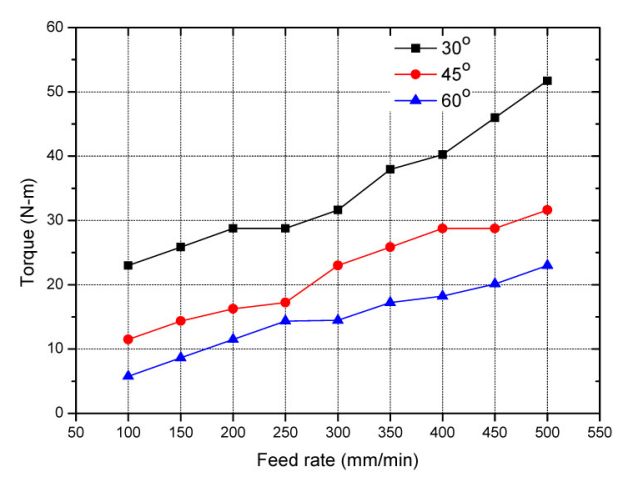

(e)

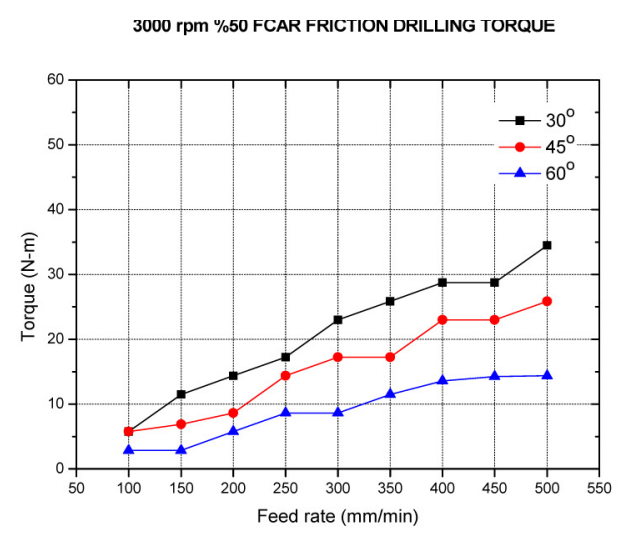

(b)

$4500 \mathrm{rpm} \% 50$ FCAR FRICTION DRILLING TORQUE

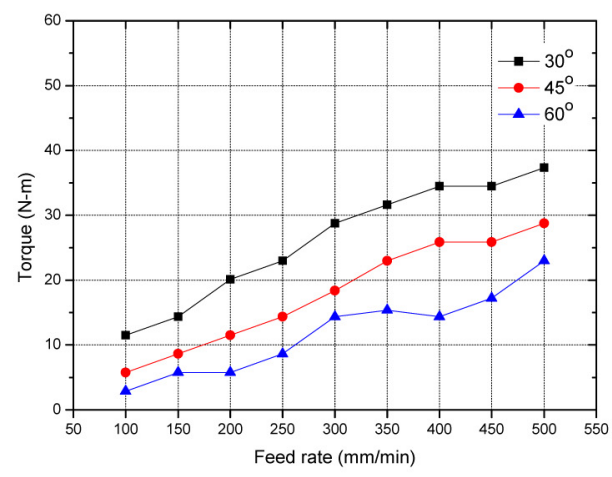

(d)

$6000 \mathrm{rpm} \% 50$ FCAR FRICTION DRILLING TORQUE

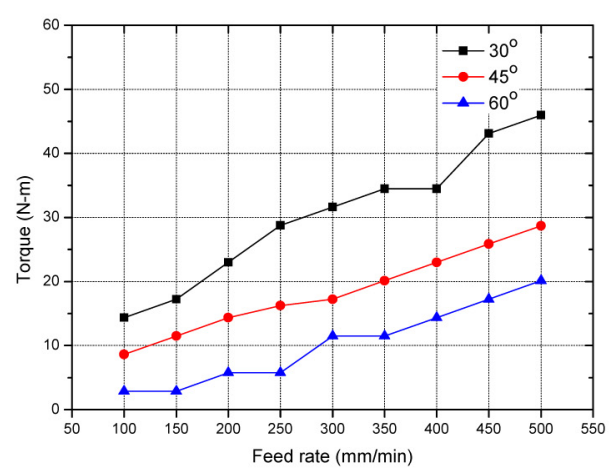

(f)

Fig. 9. Drilling torque variation with respect to different machining condition. 


\subsection{Thrust Force and Torque}

Figure 8 shows the variation in axial thrust force according to the investigated parameters. It is found that thrust force values increase due to the increasing feed rate and decreasing spindle speed. The reason is considered to be the increase in friction surface between workpiece and drilling tool. Besides it is also observed that thrust force value increases due to the increase in friction angle. The reason is that penetration of drilling tool to the workpiece becomes difficult due to increasing friction angle. High thrust force is an unwelcomed situation because it shortens life of the tool. The results are similar to those reported by Krisha et al. [4]. As seen in Fig. 8(a), the thrust forces for friction angles 30, 45 and $60^{\circ}$ are 1245, 1849 and $2268 \mathrm{~N}$, respectively.

It is also seen that friction contact area ratio has a significant effect on thrust force in constant spindle speed and feed rate. For example as observed in Figs. 8(b) and 8(c) while the FCAR decreases from 100 to $50 \%$ with spindle speed of $4500 \mathrm{rpm}$, feed rate of $100 \mathrm{~mm} / \mathrm{min}$ and friction angle of $45^{\circ}$, the thrust force decreases from 1380 to $881 \mathrm{~N}$. The reason is the increase of pressure between drilling tool and work piece due to friction contact area ratio decrease. Accordingly this causes easy deformation in workpiece. Maximum thrust force is determined as $3238 \mathrm{~N}$ with spindle speed of $3000 \mathrm{rpm}$, feed rate of $500 \mathrm{~mm} / \mathrm{min}$ and friction angle of $60^{\circ}$. Minimum thrust force is determined as $699 \mathrm{~N}$ with spindle speed of $6000 \mathrm{rpm}$, feed rate of $100 \mathrm{~mm} / \mathrm{min}$ and friction angle of $30^{\circ}$.

Figure 9 shows the drilling torque values according to examined parameters. Similar to thrust force, it is observed that drilling torque values increase due to the increasing feed rate. Minimum torque is obtained with a drilling tool having $60^{\circ}$ friction angles while the spindle speed and feed rate are $3000 \mathrm{rpm}$ and 100 $\mathrm{mm} / \mathrm{min}$, respectively (Fig. 9a). As seen in Fig. 9(e), maximum torque is obtained with a drilling tool having $30^{\circ}$ friction angles while the maximum spindle speed and feed rate are $6000 \mathrm{rpm}$ and $500 \mathrm{~mm} / \mathrm{min}$, respectively. Besides it is determined that drilling torque decreases due to the decreasing friction contact surface. The reason is the decrease of friction area.

\section{CONCLUSIONS}

This study investigates the thermal friction drilling effects on surface temperature, thrust force and torque for ST12 steel. Experimental data support the following conclusions:

- Thrust force and torque increases gradually with increasing friction angle, feed rate and FCAR.

- Thrust force and torque decreases with increasing spindle speed.

- As the spindle speed increases, the workpiece surface temperature increases.

- Increasing or decreasing the friction angle and FCAR has no significant effect on workpiece surface temperature.

- There is an increase in surface roughness as the feed rate increases.

- The bushing length decreases as the feed rate increases.

\section{ACKNOWLEDGEMENT}

One of the authors (A.A.) wishes to thank the Turkish Academy of Sciences (TUBA) for its support.

\section{REFERENCES}

1. Miller, S.F., Tao, J. and Shih, A.J., "Friction drilling of cast metals", International Journal of Machine Tools \& Manufacture, Vol. 46, Nos. 12-13, pp. 1526-1535, 2006. 
2. van Geffen, J.A., "Piercing tools”, US Patent 3939683, 1976.

3. Su, Y.L., Liu, T.H., Su, C.T., Yao, S.H., Kao, W.H. and Cheng, K.W., "Wear of CrC-coated carbide tools in dry machining", Journal of Materials Processing Technology, Vol. 171, No. 1, pp. 108-117, 2006.

4. Krishna, P.V., Kishore, K. and Satyanarayana, V.V., "Some investigations in friction drilling AA6351 using high speed steel tools", Journal of Engineering \& Applied Sciences, Vol. 5, No. 3, pp. 81-88, 2010.

5. Ku, W.L., Hung, C.L., Lee, S.M. and Chow, H.M., "Optimization in thermal friction drilling for SUS 304 stainless steel", The International Journal of Advanced Manufacturing Technology, Vol. 53, Nos. 9-12, pp. 935-944, 2011.

6. Lee, S.M., Chow, H.M. and Yan, B.H., "Friction drilling of IN-713LC cast super alloy", Materials and Manufacturing Processes, Vol. 22, Nos. 7-8, pp. 893-897, 2007.

7. France, J.E., Davidson, J.B. and Kirby, P.A., "Strength and rotational stiffness of simple connections to tubular columns using flowdrill connectors", Journal of Constructional Steel Research, Vol. 50, No. 1, pp. 15-34, 1999.

8. France, J.E., Davidson, J.B. and Kirby, P.A., "Moment-capacity and rotational stiffness of endplate connections to concrete-filled tubular columns with flowdrill connectors", Journal of Constructional Steel Research, Vol. 50, No. 1, pp. 35-48, 1999.

9. France, J.E., Davidson, J.B. and Kirby, P.A., "Strength and rotational response of moment connections to tubular columns using flowdrill connectors", Journal of Constructional Steel Research, Vol. 50, No. 1, pp. 1-14, 1999.

10. Chow, H-M., Lee, S-M. and Yang, L-D., "Machining characteristic study of friction drilling on AISI 304 stainless steel", Journal of Materials Processing Technology, Vol. 207, Nos. 1-3, pp. 180-186, 2008.

11. Miller, S.F., Blau, P.J. and Shih, A.J., "Tool wear in friction drilling", International Journal of Machine Tools and Manufacture, Vol. 47, No. 10, pp. 1636-1645, 2007.

12. Lee, S.M., Chow, H.M., Huang, F.Y. and Yan, B.H., "Friction drilling of austenitic stainless steel by uncoated and PVD AlCrN- and TiAlN-coated tungsten carbide tools", International Journal of Machine Tools and Manufacture, Vol. 49, No. 1, pp. 81-88, 2009.

13. Folea, M., Schlegel, D., Gete, E., Langlade, C. and Roman, A., "Preliminary tests on flow drilling of maraging steels", Academic Journal of Manufacturing Engineering, Vol. 10, No. 4, pp. 42-47, 2012.

14. Miller, S.F., Li, R., Wang, H. and Shih, A.J., "Experimental and numerical analysis of the friction drilling process", Journal of Manufacturing Science and Engineering, Vol. 128, No. 3, pp. 802-810, 2006.

15. Miller, S.F., Experimental Analysis and Numerical Modeling of the Friction Drilling, PhD Dissertation, University of Michigan, 2006.

16. Adachi, K., Arai, N., Okita, K., Ogawa, K. and Niba, R., "A study on drilling of SUS304 by TiN-coated drills", International Journal of the Japan Society for Precision Engineering, Vol. 24, No. 3, pp. 200-205, 1990. 